\title{
Chapter 15 \\ Mainstreaming Nature-Based Solutions for Climate Change Adaptation in Urban Governance and Planning
}

\author{
Christine Wamsler, Stephan Pauleit, Teresa Zölch, Sophie Schetke, \\ and André Mascarenhas
}

\begin{abstract}
The concept of mainstreaming climate change adaptation to foster sustainable urban development and resilience is receiving increasing interest. In particular, the need to mainstream ecosystem- or nature-based solutions into urban governance and planning is widely advocated by both academic and governmental bodies.

Adaptation mainstreaming is the inclusion of climate risk considerations in sector policy and practice. It is motivated by the need to challenge common ideas, attitudes, or activities and change dominant paradigms at multiple levels of governance. It seeks to increase sustainability and resilience by expanding the focus from preventing or resisting climate hazards - to a broader systems framework in
\end{abstract}

\footnotetext{
C. Wamsler $(\bowtie)$

Lund University Centre for Sustainability Studies, Lund, Sweden

Centre for Natural Disaster Science, Uppsala, Sweden

e-mail: christine.wamsler@lucsus.lu.se
}

S. Pauleit • T. Zölch

Centre for Urban Ecology and Climate Adaptation (ZSK) and Chair for Strategic Landscape

Planning and Management, Technical University of Munich, Munich, Germany

e-mail: pauleit@wzw.tum.de; teresa.zoelch@tum.de

S. Schetke

Institute for Geodesy and Geoinformation, University of Bonn, Bonn, Germany

e-mail: schetke@uni-bonn.de
A. Mascarenhas
Center for Environmental and Sustainability Research (CENSE),
Universidade NOVA de Lisboa, Lisbon, Portugal
Geography Department, Humboldt-Universität zu Berlin, Berlin, Germany
e-mail: andre.mascarenhas@fct.unl.pt; andre.mascarenhas@hu-berlin.de 
which we learn to live and cope with an ever-changing, and sometimes risky, environment. It aims to address the root causes of risk (including power structures) and failed approaches to sustainable development.

This chapter begins with an introduction to the concept of adaptation mainstreaming. It then presents an integrated framework that illustrates potential mainstreaming measures and strategies at different levels of governance, and discusses their application in urban planning practice with a focus on nature-based solutions. Case studies from Germany and Portugal illustrate the text. Four key principles for successful adaptation mainstreaming are highlighted. First, at the local level, adaptation mainstreaming requires the active consideration and combination of four approaches/ measures to reduce climate risk on the ground. Second, to ensure their sustainable implementation, mainstreaming strategies must be implemented at the local, institutional and interinstitutional level. Third, the different measures and strategies only lead to sustainable change in combination. Finally, experience in mainstreaming other cross-cutting issues (notably climate change mitigation) can create synergies and support progress.

However, in practice there is still a long way to go. Current approaches often remain characterised by individual actions and the creation of separate, bolted-on structures and mechanisms.

Keywords Mainstreaming - Risk reduction - Disaster risk reduction - Climate policy integration $\bullet$ Environmental policy integration $\bullet$ Resilience $\bullet$ Climate change adaptation $\bullet$ Climate change mitigation $\bullet$ Germany $\bullet$ Portugal $\bullet$ Sweden $\bullet$ UK $\bullet$ Central America $\bullet$ Brazil

\subsection{Introduction}

Climate change and related hazards are an increasing threat to urban development, which, in turn, is increasing vulnerability to these hazards by inconsiderate development choices (OECD 2009; UNISDR 2008). This trend is expected to continue. Climate change is projected to magnify the frequency and intensity of weatherrelated hazards, which already account for the majority of annual losses from disasters (IPCC 2012, 2014; UNISDR 2010).

Consequently, resilience has emerged as a central concept in international and national development policy together with the concept of mainstreaming (Pervin et al. 2013; Wilkinson et al. 2014). Today, increasing resilience through the mainstreaming (or integration) of climate risk considerations into sector work is a unifying goal for the domains of climate change adaptation and disaster risk reduction (Andrade et al. 2011; Wamsler 2014). Resilience, i.e., "[T]the ability of a system, community or society exposed to hazards to resist, absorb, accommodate to and recover from their effects (...)" (UNISDR 2009, 2015), is also a feature of related global agendas, including the Sendai Framework for Disaster Risk Reduction 20152030, Sustainable Development Goals (SDGs) and the Paris Climate Agreement. 
Against this background, the objective of this chapter is to present the key principles that show how adaptation mainstreaming can be achieved in urban governance and planning, ${ }^{1}$ and discuss its role in fostering nature-based solutions and resilience. It should be noted that the term 'climate change adaptation'2 denotes here an approach that integrates risk reduction and adaptation considerations.

\subsection{What Is Adaptation Mainstreaming?}

Adaptation mainstreaming refers to the inclusion of adaptation considerations into all sector policy and practice in order to reduce climate risk. The concept has two principal origins. One strand has developed from risk reduction mainstreaming, which has been strongly supported since the World Conference on Disaster Risk Reduction in Kobe, Japan in 2005 (UNISDR 2005), and which itself builds on mainstreaming experience in cross-cutting domains such as HIV/Aids and gender (Daly 2005; Holden 2004; Mazey 2002). The second has its roots in environmental policy integration (United Nations 1987; Lenschow 2002; Van Asselt et al. 2015), and more specifically climate policy mainstreaming, which has been promoted since around 1997 (Collier 1997). The initial objective of climate policy mainstreaming was to integrate the objective of reducing greenhouse gas emissions into other sectoral policies. Over time, the focus has gradually broadened and currently it also explicitly includes adaptation considerations (Berkhout et al. 2015; Wamsler and Pauleit 2016).

\subsection{Why Is Adaptation Mainstreaming Relevant?}

Adaption mainstreaming is particularly relevant in the context of nature-based solutions. Although climate adaptation in general, and nature-based solutions in particular are widely advocated (Daily and Matson 2009; Daily et al. 2009; Gaffin et al. 2012; Ojea 2015; Pasquini and Cowling 2014), they have not been systematically implemented (Andrade et al. 2011; IPCC 2014; Sitas et al. 2014; Vignola et al. 2009; Wamsler et al. 2014; Wamsler 2015a). Many local authorities and other urban stakeholders are unsure about what they can do to change this situation. The problem remains: how can climate adaptation be systematically mainstreamed into urban governance and planning, and ultimately increase resilience?

To answer this question, this chapter provides an integrated framework for adaptation mainstreaming. It builds upon frameworks that have been developed for mainstreaming environmental policy, climate adaptation, disaster risk reduction and

\footnotetext{
${ }^{1}$ Planning can be seen as a key sector, or avenue, for adaptation (IPCC 2014; Measham et al. 2011) and draws attention to respective governance arrangements (Agrawal 2008).

${ }^{2}$ Note that the terms "climate change adaptation", "climate adaptation" and "adaptation" are used as synonyms in this chapter.
} 
other cross-cutting domains. The framework was empirically developed and tested between 2003 and 2016 in close collaboration with governmental and nongovernmental organizations, in both developed and so-called developing countries (e.g., Germany, Sweden, the United Kingdom, Central America, Brazil), a process that has involved theoretical developments, analyses and the elaboration of practical guidelines. For more detailed information on the methodology, related case studies etc., see Wamsler (2006/2007, 2007, 2009, 2014, 2015a, b); Wamsler et al. (2014); and Wamsler and Pauleit (2016).

\subsection{The Framework: Adaptation Mainstreaming at the Local Level}

At the local level, adaptation mainstreaming requires the consideration and combination of four approaches to comprehensively reduce climate risk. All four approaches aim to reduce risk, but in different ways. They can be illustrated by the example of a potential landslide. The first approach aims to reduce (current and future) hazard exposure, which can be achieved by moving away from the landslide hazard or by reducing exposure on-site. The second approach aims to reduce vulnerability of the landslide-exposed area. Here, the aim is to create an environment that can withstand hazard impacts, without losing any of the community's main functions. The third aims to ensure an effective response post-landslide. Here the goal is to prepare response mechanisms and structures, before potential hazard impacts. Finally, the fourth approach aims to ensure effective recovery. Here, the aim is to prepare recovery mechanisms and structures, again, before potential hazard impacts.

The specific activities that are associated with each approach vary as a function of the hazard. Nevertheless, the principles do not change. For example, if the hazard is a flood rather than a landslide, the four approaches can be applied: reduce exposure, reduce vulnerability, prepare an effective response and prepare an effective recovery. Whenever possible, both multi-hazard and multi-purpose measures (i.e., measures that address both adaptation and other municipal objectives) should be implemented.

Nature-based solutions can be applied in the context of all four approaches: For example, exposure to flood can be reduced through beach nourishment, restoring or managing mangroves, or improved water management on the outskirts of urban areas. To reduce exposure to landslides, slopes can be stabilized through planting or the use of retention walls, which can combine elements of grey and green infrastructure. Careful urban planning, for example in the form of protected natural environments, can help to distance residential areas or critical infrastructure from a hazard, or at least ensure that settlements do not develop into hazard-prone areas.

With respect to reducing vulnerability, creating redundancy through naturebased solutions is an important element. Green infrastructure can help to reduce vulnerability by reducing dependency on only one system e.g. for heating, cooling, 
transportation or drainage. In addition, in the case of flood risk, measures for vulnerability reduction include the creation of buffer zones, retention ponds or increased permeable surfaces, for instance through the promotion of green roofs or urban agriculture. In the case of heat, measures include drought-resistant plants and improved insulation (e.g. through green walls).

In the context of response preparedness, typical measures include early warning systems and preparations for temporary refuge. In this context, nature-based solutions include well-designed green areas that can provide space for temporary shelter or protection (e.g., use of elevated green platforms during flash floods). Another example is the preparation of cooling mechanisms or structures. These include mobile planting systems or fountains, which can be used during heatwaves.

Recovery preparedness measures through nature-based solutions can include the use of materials or green infrastructure elements that can be easily recovered or replaced, along with preparations for post-disaster assistance. Examples are designated green areas that can be used for accommodation during reconstruction, preparations for the clearing or re-use of rubble (including green materials), or the provision of health and psychological support. The latter can include the support for greening private lots, being a multi-purpose measure with positive impacts on health and well-being. Other preparedness measures are awareness-raising campaigns and guidance on what to do after certain hazards, which can be linked to nature-based solutions (e.g. environmental learning parks). Although the contribution of naturebased solutions is often more indirect and contingent on other factors when it comes to preparedness measures, they are equally important.

It is crucial to understand and, ultimately, implement all four approaches, since local resilience is a function of inclusiveness and flexibility, rather than the effectiveness of a single approach (or measure) (Inderberg et al. 2015; Wamsler and Brink 2014; Wamsler and Pauleit 2016). Inclusiveness refers to the use of not just one or two, but all of the four risk-reducing approaches. Hence, whenever possible, measures that combine two, three or possibly all four approaches within a single activity should be preferred (e.g., in the creation of a climate park; cf., Box 15.1). Flexibility relates to the number and diversity of activities implemented for each approach, which must include both grey and green infrastructure together with socio-economic and political/institutional measures. This is crucial not only to identify multi-purpose solutions, but to also address the root causes of risk and, in turn, achieve sustainable change.

Appropriate activities for each approach must be identified for each individual context. Consideration must here be given to: (i) urban-rural linkages; (ii) urban characteristics (i.e., the urban fabric, the environment, economic and governance systems); and (iii) inter-area differences ${ }^{3}$ (Wamsler, 2014; Wamsler and Brink 2016a). The latter can be characterized in terms of inclusion-exclusion, integrationmarginalization, wealth-poverty, equality-inequality, and formality-informality. ${ }^{4}$

\footnotetext{
${ }^{3} \mathrm{~A}$ framework for analyzing urban-rural differences and linkages, and how they relate to weather and non-weather-related hazards is presented in Wamsler (2014) and Wamsler and Brink (2016a). ${ }^{4} \mathrm{~A}$ framework for a systematic vulnerability and capacity assessment that can identify appropriate risk-reduction measures is presented in Wamsler (2014).
} 


\section{Box 15.1 Magdalenenpark - A Climate Park for Munich, Germany}

In 2013-2014, the NGO 'BUND Naturschutz' and the City of Munich, in cooperation with a team of landscape architects from the Technical University of Munich developed the design for a climate park. What is a climate park? It is an urban green space that: (i) is adapted to climate change; (ii) positively influences the microclimate; and (iii) stimulates citizens' adaptive awareness and behaviour (Brandl et al. 2014). Consistent with the four risk-reducing approaches introduced in this chapter, holistic adaptation measures were developed to address risk, and the microclimate modelling tool EnviMet was used to evaluate the design. This highlighted several features. First, increased vegetation improves thermal comfort and can reduce exposure to heat (Approach 1). Second, a variety of plants (e.g., drought-resistant species) increases the diversity of flora and reduces its vulnerability to heat stress (Approach 2). Third, it is important to select plants and materials (e.g., for benches) that can easily recover from heat or precipitation events (Approach 4). Finally, the park provides nearby residents from large housing estates with a place of refuge and temporary shelter during strong winds, precipitation or heat (Approach 3). The design is complemented by a pedagogical concept, related to all four risk-reducing approaches (Strategy VI). This includes providing information on adaptive behaviour, climate change and climate variability, and demonstrating the influence of different types of surfaces and vegetation covers. It also provides an opportunity to study the phenology of seasonal vegetation (e.g. bulbs that flower in early spring along hedges and in woodland, flowering cherries and meadows in summer, and fruit harvesting in autumn). The climate park is planned for an existing open green space in the western suburb of Neuaubing, but its implementation requires further negotiation with the landowner. Land ownership issues are a common challenge and highlight the importance of linking on-the-ground measures with mainstreaming strategies at institutional and interinstitutional level to ensure their sustainable implementation as described in this chapter.

All of the above approaches/measures and considerations only apply to mainstreaming at the local or operational level. However, also organizations themselves need to change (procedures, organizational structures, policies and regulations, etc.), rather than simply 'mainstreaming' change into selected on-the-ground activities (Persson and Klein 2009; Van Asselt et al. 2015; Wamsler and Pauleit 2016). 


\subsection{The Framework: Adaptation Mainstreaming at the (Inter)Institutional Levels}

Mainstreaming needs to take place at the local (operational), institutional and the interinstitutional ${ }^{5}$ level in order to achieve sustainable change and to unite top-down and bottom-up efforts that together create a holistic and distributed governance system for climate adaptation (Fig. 15.1). To assure the sustainable implementation of the local approaches/measures presented in the previous section, there must also be changes at the institutional and interinstitutional levels in order to:

- Institutionalize adaptation so that its integration at local level becomes standard procedure, which also includes the creation of mechanisms and structures for monitoring and learning;

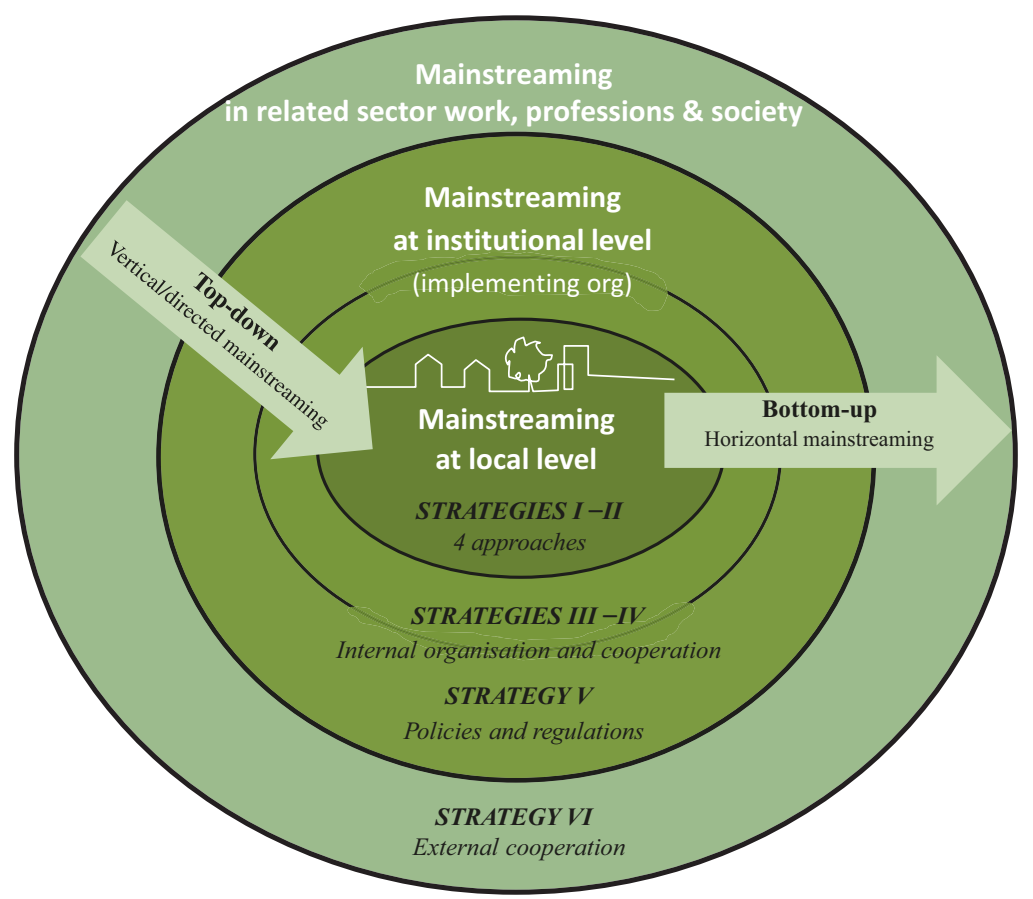

Fig. 15.1 Mainstreaming framework

\footnotetext{
${ }^{5}$ Here, the institutional level refers to the implementing organization. The interinstitutional level refers to the interlinkages between the implementing organization and other actors, to mainstream adaptation into related sector work, professions and society as a whole (Fig. 15.1).

${ }^{6}$ The issue of learning is crucial to build resilience. The four key features of resilience are anticipation, recognition, adaptation and learning (Becker 2014), which are an inherent part of the framework presented here.
} 
- Ensure that organizations themselves can continue to function during climate change impacts;

- Cooperate in creating a multilevel governance system for climate adaptation that also includes citizens and, where possible;

- Drive improved education on adaptation mainstreaming and science-policy integration.

In sum, six mainstreaming strategies operate at the three levels (local, institutional and interinstitutional). ${ }^{7}$ They are illustrated in Fig. 15.1 and Boxes 15.1, 15.2, 15.3 and 15.4. The first two (Strategies I-II) focus on the local or household level and relate to the way the four risk-reducing approaches (outlined above) are included in on-theground initiatives (either integrated or added on). Three strategies focus on the institutional level and address issues of internal organization (Strategy III) and cooperation (Strategy IV), together with policies and regulations (Strategy V). For example, it is crucial to ensure that organizational procedures and routines foster, rather than hamper (cf. Uittenbroek 2016), the implementation of nature-based solutions. The sixth strategy (Strategy VI) focuses on the interinstitutional level, external cooperation with other organizations (local, regional, national and international) and citizens. It addresses sector work, professional training and society in general.

At the institutional and interinstitutional level, mainstreaming involves both targeted and implicit integration. At the institutional level, municipalities' mainstreaming strategies can include the development of standalone adaptation strategies, the creation of interdepartmental working groups for climate change adaptation, and the integration of adaptation objectives into sectoral policies and instruments (e.g. green structure plans), comprehensive or detailed planning (cf. Wamsler 2015a; cf., Boxes 15.1, 15.2, 15.3 and 15.4). Strategies addressing the interinstitutional level can include municipal participation in regional innovation platforms that aim to create new business and cooperation models for financing nature-based solutions for climate adaptation, or the creation of city-citizen collaboration (cf. Wamsler 2015a). Unlike other mainstreaming frameworks that address targeted and implicit integration separately (cf. Uittenbroek 2016), the framework that is presented here includes both since related actions and processes are fluent and mutually supportive.

Politics and power must be explicitly addressed at all three mainstreaming levels, as they are a potential root cause of risk and represent avenues (or barriers) to transformation (cf., Boxes 15.1 and 15.4). The analysis of power (relations) is thus a precondition to sustainable change and to understand how transformation can be achieved or be hindered (Daly 2005; Digeser 1992; Partzsch 2015). This should include an evaluation of shared power (power with, cooperation and learning), the exercise of power (power to, resistance and empowerment) and power over others (coercion and manipulation) in potential mainstreaming approaches and strategies (cf. Allen 1998; Verloo 2005). Issues related to power need to be fundamentally challenged whenever and wherever modernity and globalization lead societies down an unsustainable road (Manuel-Navarrete 2010).

\footnotetext{
${ }^{7}$ For detailed definitions of the six strategies see Wamsler and Pauleit (2016).
} 


\section{Box 15.2 Urban River Restoration - The 'Isarplan' Project in Munich, Germany}

The river Isar is the most important green corridor in the city of Munich. Since the beginning of the 19th century this pre-alpine river has been increasingly regulated, both to reduce the risk of flooding and for power generation. However, flood risk and legal requirements related to flood protection necessitated its fundamental redesign. The Isarplan project was implemented in 2000-2011, and the main objectives were: (i) to improve flood control; (ii) to restore the river's ecological functions; and (iii) to improve recreational opportunities for the city's population. The city of Munich and the Regional Office for Water Management were responsible for its planning and implementation. The obvious solution was to continue to elevate the river's dams. However, the project provided an opportunity to explore a novel approach to ecological restoration, which would meet all three objectives. Consequently, the river bed was widened into surrounding flood plains, existing embankments were removed, and a naturalistic system of riverbed rock ramps was implemented that allowed fish to move upstream. (Oppermann 2005; Pauleit 2005; Pauleit and Kollmann 2015).

The Isarplan project is a good example of mainstreaming nature-based solutions for climate adaptation in urban planning at local and institutional levels. At the local level, the restoration of natural river banks and the widening of its channel reduced exposure to flood risk (Approach 1, Strategy I). The expansion of flood plains within the city created buffer zones that reduced vulnerability (Approach 2, Strategy I). Nature-based solutions are now also being planned for adjacent neighbourhoods, e.g., more greened routes that reduce risk and improve multipurpose recreation facilities (Approaches 2-4, Strategies I-II). Finally, water quality has been improved to the point where it is now possible to swim in the river. This was achieved by modernising sewage treatment plants in upstream municipalities. At the institutional level, an interdepartmental working group was responsible for coordinating the project; this group provided support and fostered a multi-benefit approach (Strategies III-IV). In addition, the project was designed by an interdisciplinary group of engineers, landscape architects, city planners and biologists, both internal and external to the city administration (Strategy VI). Today, the river Isar has been successfully transformed-not only into an appealing green space-but also into a support for comprehensive flood protection and management. 


\section{Box 15.3 Mainstreaming Climate Adaptation into Settlement Development in Bonn, Germany}

The City of Bonn uses a four-step approach to advance mainstreaming of nature-based solutions for climate change adaptation in the development of new residential areas (Helbig and Gädker 2015):

1. Cross-departmental information events on climate change (involving urban planning, urban drainage, environment, urban greening and health departments) and follow-up events to discuss options, strategies and tradeoffs with regional actors (politicians, scientists and public utility companies) (Strategy VI).

2. Educational events moderated by scientists that broaden the knowledge base of city administrators and council members in terms of climate modeling, exceptional rain events and heat stress (Strategy IV).

3. The launch of an integrated climate protection concept, which includes a section on adaptation measures (science, management and administration) (Strategy V).

4. Mainstreaming of climate adaptation into municipal working routines and local settlement development (Strategies II and III).

These four steps include a broad range of actors and decision-makers from sectors that are both internal and external to the city administration. Whilst the first two steps aim to build a shared knowledge base about the impacts of climate change, the third and fourth aim to sustainably mainstream climate change adaptation at the local and institutional levels (internal cooperation and policies). In order to enrich the discussion and provide insights into the options for implementing nature-based solutions in residential areas, the municipality has also asked the University of Bonn (the Department of Urban Planning and Real Estate Development) to develop prototype scenarios for a potential infill site (Kötter et al. 2014). These scenarios, which were developed in the context of student seminars, focus on vulnerability reduction for local residents (Approach 2), while other types of risk-reducing approaches and their anchoring at institutional levels are excluded. 


\section{Box 15.4 The Lisbon Metropolitan Area's Ecological Network}

The Lisbon Metropolitan Area (LMA) in Portugal is considered to be highly vulnerable to global climate change (Giorgi and Lionello 2008). As the region with the biggest population concentration, climate adaptation is a pressing issue for spatial and environmental planning.

The 2002 LMA Regional Spatial Plan defined a Metropolitan Ecological Network (MEN), which created a knowledge base of nature-based solutions for adaptation. The MEN defines areas and ecological corridors, which are organised into three hierarchical levels according to their importance for the environmental structure. Each level includes strategic guidelines and concrete climate change adaptation measures (mainly vulnerability reduction; Approach 2), as well as management requirements that ensure mainstreaming at the institutional level (e.g., policy and regulations - Strategy V, municipal responsibilities and financial resources - Strategy III). A noteworthy feature of the MEN is that it provides an integrated and consistent overview of designated nature conservation areas (Natura 2000 sites, natural parks, nature reserves, protected landscapes) and other ecologically-relevant areas. The lowest hierarchical level includes compact or fragmented urban areas that carry out important functions. The aim is to integrate these areas, designated as urban green zones, into municipal adaptation planning (Strategy V).

Whilst the MEN is expected to contribute to adaptation mainstreaming at the local level, it mainly addresses changes at the institutional and interinstitutional levels of governance. It can also be seen as a multi-purpose measure; although it is principally aimed at nature conservation, at the same time it supports ecosystem services that are relevant for climate change adaptation.

Its implementation highlights the potential for a governance framework with an expanded focus - from preventing or resisting climate hazards, to broader systems thinking. In 2013-2014, a participatory exercise was conducted in the LMA with stakeholders from local authorities, the national environmental authority and academia, who identified the MEN, and urban green space in general, as important drivers for sustainable planning (Mascarenhas et al. 2016).

Numerous challenges remain for mainstreaming nature-based solutions into planning practice in LMA. In addition to a fragmented institutional structure and power struggles, there is still insufficient knowledge about existing ecosystem services, how they affect human well-being and how they are, in turn, affected by planning decisions. 


\subsection{From Theory to Practice: Gaps and Synergies}

In practice, mainstreaming can create synergy effects by promoting innovation in sector-specific policies, linking and aligning sector-specific and adaptation objectives, and encouraging more efficient use of human, physical and financial resources (Lafferty and Hovden 2003; Adelle and Russel 2013; Rauken et al. 2014; Runhaar et al. 2014; Dewulf et al. 2015; Persson et al. 2015). The framework presented here can support such developments, guide an organization's mainstreaming process and hold decision-makers accountable for any promises they may make in their endeavours. It provides an overall context for action and can be applied in combination with other frameworks that target particular mainstreaming levels, strategies or approaches, such as financial integration or internal risk management (CDKN 2015; Pervin et al. 2013; UNDP 2010; UNDP-UNEP 2011).

The mainstreaming framework presented here formed the cornerstone for the development of three operational guidelines that translate the mainstreaming theory into practice. The guidelines were developed for different urban stakeholders, including non-governmental organizations (Wamsler 2006/2007, 2009) and local authorities (Wamsler 2015b; Wamsler and Brink 2016b). The latter aim to assist municipal officials and local politicians to both assess and progress the mainstreaming of climate change adaptation into planning and governance mechanisms.

The first step in this process is to categorize existing and planned activities relevant for climate adaptation according to the mainstreaming level and the strategy they address. Questions include: What kind of activities are implemented at the local, institutional or interinstitutional level? Do activities at the institutional level address the integration of climate adaptation into the overall planning vision, comprehensive planning, detailed planning, related planning instruments, the internal organizational structure, and human and financial assets? In the second and third steps, existing and planned activities are assessed against established benchmarks. This includes an assessment of the use of the four risk-reducing approaches and related synergy creation, whether a single or multi-hazard approach is adopted, and whether physical, socio-economic, environmental and political/ institutional measures are implemented at different levels. The outcome of this assessment provides a clear overview of current progress and helps to identify gaps or ways to improve (for further details, see the operational guidelines presented in Wamsler 2015b; Wamsler and Brink 2016b).

Both the mainstreaming theory and the related guidelines have proven to be very useful, and their application has helped cities in the identification of various gaps. These gaps also highlight how mainstreaming and resilience are interlinked. Here, we focus on three specific examples: (i) the lack of systematic mainstreaming of nature-based solutions; (ii) the focus on municipal self-reliance or governing; and (iii) fragmented climate policy mainstreaming.

The first gap, the lack of systematic mainstreaming of nature-based solutions (which requires a combination of the presented approaches and strategies), is illustrated by the following statement by a member of staff from a German municipality: 
"We deal with the issue of adaptation in a very broad or general sense, and the differentiation between constructive and other types of adaptation measures [i.e., nature-based solutions] is, in practice, not yet a topic. We are not there yet [...] We have a smörgasbord of ideas, we still don't have an overview. This will come with further conceptualization (Wamsler 2015a). These words provide a link back to the starting point of this chapter. Specifically, they refer to the need for a better understanding and the systematic implementation of nature-based solutions to increase resilience (e.g. to overcome the current focus on grey infrastructure solutions in on-the-ground initiatives) (Wamsler et al. 2016).

The second gap is a lack of cooperation with other stakeholders to support nature-based solutions. This is illustrated by the following statement by a member of staff from a German municipality, "The first step now is [...] we are focusing on what we can do [...] what we can implement ourselves. And then we will look, after that, further afield, and try to involve others [e.g. private actors or citizens]" (Wamsler 2015a). This statement illustrates the widespread phenomenon of municipal self-reliance in climate adaptation. At the same time the importance of involving other stakeholders is generally acknowledged, especially in the context of naturebased solutions, "We are more and more dependent [...] on everybody, every citizen must become active and get engaged, because the city cannot handle it [climate hazards] by itself anymore. The city depends on citizens' support" (Wamsler 2015a).

The third gap is fragmented climate policy mainstreaming, also regarding naturebased solutions. Specifically, it concerns the failure to integrate climate mitigation and climate adaptation mainstreaming. This is illustrated by the following statement from a staff member from a German municipality responsible for climate adaptation, "I am not sure who is responsible for climate mitigation [...] and related mainstreaming processes. It is dealt with separately" (Wamsler 2015a). This fragmented approach can hamper progress, as sustainable urban development requires integrated planning policy and practice. In addition, research has shown that adaptation mainstreaming can be spurred by an organization's experience with mainstreaming climate change mitigation (Wamsler and Pauleit 2016).

\subsection{Conclusions}

The mainstreaming of nature-based solutions for climate change adaptation can support incremental and transformative changes that address the root causes of risk and lead to sustainable development. Its implementation requires the consideration of four key principles. First, at the local level, all four approaches/ measures aimed at reducing climate risk on the ground have to be addressed, with nature-based solutions offering a broad range of applications. Second, mainstreaming strategies must be implemented at the local, institutional and interinstitutional levels in order to ensure the sustainable implementation of on-the-ground measures, and challenge current practice and procedures at multiple levels of governance. Third, measures and strategies can only lead to sustainable change in combination. Finally, previous 
experience in mainstreaming other cross-cutting issues (in particular climate change mitigation) can help to create synergies and progress adaptation mainstreaming.

Adaptation mainstreaming is a potentially effective way to foster urban resilience. In fact, the concept of mainstreaming is inherently linked to the concept of resilience, as it aims to challenge familiar ideas, attitudes, or activities and change dominant paradigms at multiple levels of governance. It can help to increase resilience by expanding the focus - from preventing or resisting hazards - to a broader systems framework in which the different stakeholders learn to live and cope with an ever-changing, and sometimes risky, environment. It can also lead to a more inclusive planning and risk governance system, which translates into the ability to change in response to altered circumstances and to carry on functioning even when individual parts fail. This can be achieved by including and linking physical, social, economic, environmental and political/ institutional aspects, different risk-reduction approaches and sector work, together with climate adaptation and mitigation considerations. Finally, the issue of power structures must be considered in any current (or potential) mainstreaming approaches or strategies.

As it stands today, practice remains characterised by individual measures, the creation of bolted-on structures, and related actions that are often seen purely as managerial governance exercises. A more systematic approach to mainstreaming nature-based solutions (as presented in this chapter), which also explicitly considers power structures, is urgently needed in order to ensure that root causes of risk and any avenues (or barriers) to transformation are addressed.

\section{References}

Adelle C, Russel D (2013) Climate policy integration: a case of déjà vu? Environ Policy Gov 23:1-12 Agrawal A (2008) The role of local institutions in adaptation to climate change. Paper prepared for the Social Dimensions of Climate Change, Social Development Department, The World Bank, Washington

Allen A (1998) Rethinking power. Hypatia 13(1):21-40

Andrade A, Córdoba R, Dave R, Girot P, Herrera-F B, Munroe R, Oglethorpe J, Paaby P, Pramova E, Watson J, Vergara W (2011) Draft principles and guidelines for integrating ecosystem-based approaches to adaptation in project and policy design. Policy brief, CATIE no. 46

Becker P (2014) Sustainability science: managing risk and resilience for sustainable development. Elsevier, Amsterdam and Oxford

Berkhout F, Bouwer LM, Bayer J, Bouzid M, Cabeza M, Hanger S, Hof A, Hunter P, Meller L, Patt A, Pfluger B, Rayner T, Reichardt K, van Teeffelen A (2015) European policy responses to climate change: progress on mainstreaming emissions reduction and adaptation. Reg Environ Chang 15:949-959

Brandl A, Keller R, Pauleit S (2014) Magdalenenpark - Ein Klimapark für München. Final project report. München, Germany

CDKN (2015) Mainstreaming climate compatible development. Chapter 4: resourcing climate compatible development

Collier U (1997) Sustainability, subsidiarity and deregulation: new directions in EU environmental policy. Environ Pollut 6(2):1-23 
Daily GC, Matson P (2009) Ecosystem services: from theory to implementation. Proc Natl Acad Sci U. S. A. 105:9455-9456

Daily GC, Polasky S, Goldstein J, Kareiva PM, Mooney HA, Pejchar L, Ricketts TH, Salzman J, Shallenberger R (2009) Ecosystem services in decision making: time to deliver. Front Ecol Environ 7:21-28

Daly M (2005) Gender mainstreaming in theory and practice. Soc Policy 12(3):433-450

Dewulf A, Meijerink S, Runhaar H (2015) Editorial for the special issue on the governance of adaptation to climate change as a multi-level, multi-sector and multi-actor challenge: a European comparative perspective. J Water Climate Change 6(1):1-8

Digeser P (1992) The fourth face of power. J Politics 54(4):977-1007

Gaffin SR, Rosenzweig C, Kong A (2012) Adapting to climate change through urban green infrastructure. Nat Clim Chang 2(10):704-704

Giorgi F, Lionello P (2008) Climate change projections for the Mediterranean region. Glob Planet Chang 63:90-104

Helbig J, Gädker J (2015) Initiierung und Entwicklung von Klimaanpassungsaktivitäten in der Stadt Bonn, In: (Difu), S.K.K.K. beim D.I. für U.G. (Ed.), Klimaschutz \& Klimaanpassung. Themenhefte, Köln, p 46-53

Holden S (2004) Mainstreaming HIV/AIDS in development and humanitarian programmers. Oxfam GB, Oxford

Inderberg TH, Eriksen S, O'Brien K, Sygna K (2015) Climate change adaptation and development: transforming paradigms and practices. Routledge, New York

IPCC (2012) Managing the risks of extreme events and disasters to advance climate change adaptation. SREX report. Cambridge University Press, Cambridge, UK

IPCC (2014) Climate change 2014: impacts, adaptation, and vulnerability. Cambridge University Press, Cambridge, UK

Kötter T, Schetke S, Katzschner L (2014) Das quartier "Gymnicher Hof," MSc seminar on urban renewal. Msc-programm geodesy and geoinformation. University of Bonn, Bonn

Lafferty W, Hovden E (2003) Environmental policy integration: towards an analytical framework. Environ Pollut 12(3):1-22

Lenschow A (ed) (2002) Environmental policy integration: greening sectorial policies in Europe. Earthscan, London, UK

Manuel-Navarrete D (2010) Power, realism, and the ideal of human emancipation in a climate of change. Wiley Interdiscip Rev Clim Chang 1(6):781-785

Mascarenhas A, Ramos TB, Haase D, Santos R (2016) Participatory selection of ecosystem services for spatial planning: Insights from the Lisbon Metropolitan Area, Portugal. Ecosyst Serv 18:87-99

Mazey S (2002) Gender mainstreaming strategies in the EU. Fem Leg Stud 10:227-240

Measham TG, Preston BL, Smith TF, Brooke C, Gorddard R, Withycombe G, Morrison C (2011) Adapting to climate change through local municipal planning: barriers and challenges. Mitig Adapt Strateg Glob Chang 16:889-909

OECD (2009) Integrating climate change adaptation into development co-operation: policy guidance. OECD Publishing, Paris, France p 197

Ojea E (2015) Challenges for mainstreaming ecosystem-based adaptation into the international climate agenda. Curr Opin Environ Sustain 14:41-48

Oppermann B (2005) Redesign of the River Isar in Munich, Germany Getting coherent quality for green structures through competitive process design? In: Werquin AC, Duhem B, Lindholm G, Oppermann B, Pauleit S, Tjallingii S (eds) Green structure and urban planning (Vol COST Action C11). European Commission, Brussels

Partzsch, L (2015) Kein Wandel ohne Macht - Nachhaltigkeitsforschung braucht ein mehrdimensionales Machtverständnis. GAIA - Ecol Perspect Sci Soc 24(1):48-56 (9)

Pasquini L, Cowling R (2014) Opportunities and challenges for mainstreaming ecosystem-based adaptation in local government: evidence from the Western Cape, South Africa. Environ Dev Sustain 17:1-20 
Pauleit S (2005) Munich. In: Werquin AC, Duhem B, Lindholm G, Oppermann B, Pauleit S, Tjallingii S (eds) Green structure and urban planning (Vol COST Action C11). European Commission, Brussels

Pauleit S, Kollmann J (2015) Die Isarrenaturierung in München. Hochwasserschutz, Ökologie und Erholung integrativ? In: DGGL Jahrbuch 2015, pp. 34-39

Persson Å, Klein RJT (2009) Mainstreaming adaptation to climate change into official development assistance: Building on environmental policy integration theory. In: Harris P (ed) Climate change and foreign policy: case studies from East to West. Routledge, London, pp 162-177

Persson $\AA$, Eckerberg K, Nilsson M (2015) Institutionalization or wither away: 25 years of environmental policy integration in Swedish energy and agricultural policy under shifting governance models in Sweden. Environ Plann C 47:1-18

Pervin M, Sultana S, Phirum A, Camara IF, Nzau VM, Phonnasane V, Khounsy P, Kaur N, Anderson S (2013) A framework for mainstreaming climate resilience into development planning. IIED Working Paper, Climate Change

Rauken T, Mydske PK, Winsvold M (2014) Mainstreaming climate change adaptation at the local level. Local Environ 20(4):408-423

Runhaar H, Driessen PJ, Uittenbroek C (2014) Towards a systematic framework for the analysis of environmental policy integration. Environmental Policy and Governance 24(4):233-246

Sitas N, Prozesky H, Esler K, Reyers B (2014) Exploring the gap between ecosystem service research and management in development planning. Sustainability 6:3802-3824

UNDP (2010) Mainstreaming disaster risk reduction into development at the national level: a practical framework

UNDP-UNEP (2011) Mainstreaming climate change adaptation into development planning: a guide for practitioners. Environment for the MDGs. UNDP-UNEP Poverty-Environment Initiative

UNISDR (2005) Hyogo framework for action 2005-2015: building resilience of nations and communities to disasters. World conference on disaster reduction, Kobe, Hyogo, Japan

UNISDR (2008) Links between disaster risk reduction, development and climate change: A briefing for Sweden's Commission on Climate Change and Development. p. 5

UNISDR (2009) Terminology on disaster risk reduction. UNISDR Online Glossary. https://www. unisdr.org/we/inform/terminology\#letter-r

UNISDR (2010) Briefing note 03: strengthening climate change adaptation through effective disaster risk reduction. p. 10

UNISDR (2015) Sendai framework for disaster risk reduction 2015-2030. World conference on disaster reduction, Sendai, Japan

United Nations (1987) Our common future - Brundtland report. Oxford University Press, Oxford

Uittenbroek CJ (2016) From policy document to implementation: organizational routines as possible barriers to mainstreaming climate adaptation. J Environ Policy Plan 18(2):161-176

Van Asselt H, Rayner T, Persson $\AA$ (2015) Climate policy integration. In: Bäckstrand K, Lövbrand E (eds) Research handbook on climate governance. Edward Elgar, Cheltenham, UK, chapter 34, 24:388-399

Verloo M (2005) Displacement and empowerment: Reflections on the concept and practice of the council of Europe approach to gender mainstreaming and gender equality. Soc Policy 12(3):344-365

Vignola R, Locatelli B, Martinez C, Imbach P (2009) Ecosystem-based adaptation to climate change: what role for policy-makers, society and scientists? Mitig Adapt Strateg Glob Chang 14:691-696

Wamsler C (2007) Managing Urban Disaster Risk: Analysis and Adaptation Frameworks for Integrated Settlement Development Programming for the Urban Poor, Dec. 2007, Doctoral thesis, Lund: Lund University

Wamsler C (2006/2007) Operational Framework for Integrating Risk Reduction for Aid Organisations Working in Human Settlement Development [English and Spanish version], Benfield Hazard Research Centre (BHRC) Disaster Studies Working Paper No. 14, London: BHCR 
Wamsler C (2009) Operational Framework for Integrating Risk Reduction and Climate Change Adaptation into Urban Development, Brookes World Poverty Institute (BWPI), Working Paper Series No. 101, Manchester: BWPI

Wamsler C (2014) Cities, disaster risk and adaptation. Routledge, London

Wamsler C, Brink E (2014) Moving beyond short-term coping and adaptation. Environ Urban 26:1-26, special issue on 'Towards Resilience and Transformation for Cities'.

Wamsler C, Luederitz C, Brink E (2014) Local levers for change: mainstreaming ecosystem-based adaptation into municipal planning to foster sustainability transitions. Glob Environ Chang 29:189-201

Wamsler C (2015a) Mainstreaming ecosystem-based adaptation: transformation toward sustainability in urban governance and planning. Ecol Soc 20(2):30

Wamsler C (2015b) Guideline for integrating climate change adaptation into municipal planning and governance. Working Paper 31. Disaster Studies and Management Working Paper Series, University College London (UCL) Hazard Centre, London.

Wamsler C, Brink E (2016a) The urban domino effect: a conceptualization of cities' interconnectedness of risk. Int J Disaster Resilience Built Environ 7(2):80-113

Wamsler C, Brink E (2016b) Promoting nature-based solutions: guideline for integrating ecosystem-based adaptation into municipal planning and governance, Disaster Studies and Management Working Paper 32. UCL, London. Accessible online. http://www.ucl.ac.uk/ hazardcentre/resources/working_papers/working_papers_folder/UCLDisasterStudies ManagementWorkingPaper32

Wamsler C, Niven L, Beery T, Bramryd T, Ekelund N, Jönsson I, Osmani A, Palo T, Stålhammar S (2016) Operationalizing ecosystem-based adaptation: harnessing ecosystem services to buffer communities against climate change. Ecol Soc 21(1):31

Wamsler C, Pauleit S (2016) Making headway in climate policy mainstreaming and ecosystembased adaptation: two pioneering countries, different pathways, one goal. Springer, Climatic Change, Netherlands

Wilkinson E, Carabine E, Peters K, Brickell E, Scott A, Allinson C, Jones L, Bahadur A (2014) Existing knowledge integrating disaster risk reduction, environment and climate change into development practice. ODI Advancing Integration Series Working Paper. Overseas Development Institute, London

Open Access This chapter is licensed under the terms of the Creative Commons Attribution 4.0 International License (http://creativecommons.org/licenses/by/4.0/), which permits use, sharing, adaptation, distribution and reproduction in any medium or format, as long as you give appropriate credit to the original author(s) and the source, provide a link to the Creative Commons license and indicate if changes were made.

The images or other third party material in this chapter are included in the chapter's Creative Commons license, unless indicated otherwise in a credit line to the material. If material is not included in the chapter's Creative Commons license and your intended use is not permitted by statutory regulation or exceeds the permitted use, you will need to obtain permission directly from the copyright holder. 